\title{
The Innovation and Development of the Small Micro-finance: the road to a Win-win Situation of Small Micro-enterprise and Small and Medium-sized Bank
}

\author{
TingXuan Zhu \\ Department of Economics and Management, North China Electric Power University, Baoding City, \\ China \\ Email: 2439881868@qq.com
}

Keywords: Small micro-finance; Internet finance; Big data

\begin{abstract}
The problem of financing difficulties has always been the bottleneck of restricting the existence and development of the small micro- enterprise. The article mainly discussed how to solve the problem of financing difficulties, and the innovative development of the small micro-finance. It also suggests that the small and medium-sized banks should seize the opportunity, adopt the idea of big data analytics, and speed up self-reform with the help of the Internet finance in order to work out a win-win road with the small-micro enterprise.
\end{abstract}

\section{Introduction:}

The small micro-enterprise is the generic terms of small businesses, micro enterprises cottage industry enterprises and individual businesses. In China, the small micro-enterprise is the main channel to offer new jobs, the important platform for the country to encourage entrepreneurship as well as the significant driving force to promote the innovation of science and technology. Since it is greatly concerned with the overall situation of promoting employment, improving people's livelihood, economic development and the stability of the society, the vitality of small micro-enterprise directly influences the boom and bust of China's market economy. However, the problem of financing difficulty has always been the bottleneck of the survival and progress of the small micro-enterprise. In the Boao Forum for Asia (BFA) Annual Conference 2014, one report of small micro-finance has pointed out that the financing problem of the small micro enterprise is a global one. But the problem of financing difficulty in Asian countries is still particularly serious because of the undeveloped financial system. So the innovation and development of the small micro-finance are extremely urgent.

Table1. The date of statistic

\begin{tabular}{|c|c|c|c|c|c|}
\hline $\begin{array}{c}\text { The } \\
\text { quantity of } \\
\text { the small } \\
\text { micro } \\
\text {-enterprise }\end{array}$ & $\begin{array}{c}\text { The } \\
\text { quantity of } \\
\text { the } \\
\text { enterprise } \\
\text { proportion } \\
\text { of the small } \\
\text { micro } \\
\text { enterprise } \\
\text { occupying } \\
\text { the } \\
\text { enterprise }\end{array}$ & $\begin{array}{c}\text { The quantity of the } \\
\text { small micro } \\
\text {-enterprise(including } \\
\text { individual } \\
\text { enterprise) }\end{array}$ & $\begin{array}{c}\text { The } \\
\text { The quantity of the } \\
\text { enterprise(including } \\
\text { individual } \\
\text { enterprise) }\end{array}$ & $\begin{array}{c}\text { proportion } \\
\text { of the small } \\
\text { micro } \\
\text {-enterprise } \\
\text { occupying } \\
\text { the } \\
\text { enterprise }\end{array}$ \\
\hline 11698700 & 15278400 & $76.57 \%$ & 5606.16 & 5964.13 & $94.15 \%$ \\
\hline
\end{tabular}

Table2. The occupation of the small micro enterprise in kinds of enterprise

\begin{tabular}{|c|c|c|c|c|}
\hline & $\begin{array}{c}\text { Overseas-funded } \\
\text { enterprise }\end{array}$ & $\begin{array}{c}\text { State-owned } \\
\text { collective } \\
\text { enterprise }\end{array}$ & $\begin{array}{c}\text { The private } \\
\text { enterprise }\end{array}$ & $\begin{array}{c}\text { The private } \\
\text { enterprise(including } \\
\text { the individual } \\
\text { enterprise) }\end{array}$ \\
\hline $\begin{array}{c}\text { The occupation } \\
\text { of the small } \\
\text { micro enterprise }\end{array}$ & $53.94 \%$ & $61.39 \%$ & $80.72 \%$ & More than97\% \\
\hline
\end{tabular}


Table3. The balance of the loan from the middle and small-sized enterprises, In Beijing 2011 January to September (unit : hundred million)

\begin{tabular}{|c|c|c|c|c|}
\hline Month & $\begin{array}{c}\text { The small and } \\
\text { medium-sized } \\
\text { enterprise loan } \\
\text { balance } \\
\text { (excluding notes) }\end{array}$ & $\begin{array}{c}\text { Year-on-year } \\
\text { growth rate(\%) }\end{array}$ & $\begin{array}{c}\text { The small } \\
\text { enterprise loan } \\
\text { balance } \\
\text { (excluding notes) }\end{array}$ & $\begin{array}{c}\text { Year-on-year } \\
\text { growth rate(\%) }\end{array}$ \\
\hline 1 & 7715.7 & & & \\
\hline 2 & 7756.4 & & & \\
\hline 3 & 7894.7 & 27.9 & & 47.8 \\
\hline 4 & 7947.6 & 26.9 & & 21.7 \\
\hline 5 & 7873.2 & 23.9 & 2656.9 & 50 \\
\hline 6 & 7925 & 21.7 & & 49.6 \\
\hline 7 & 7910.2 & 21.4 & 2731.9 & \\
\hline 8 & 7999.2 & 21 & 2603.1 & 2846.8 \\
\hline 9 & 8038.2 & 20.3 & & \\
\hline
\end{tabular}

We can see the phenomenon that the bank give the medium enterprise more loan than the small enterprise from the date. We can also foresee that the micro- enterprise will get less loan inevitably. The problem of financing difficulty can be seen from the current situation that the small-micro enterprise get the loan from the bank.

The road of innovation and development of the small micro- enterprise is also a road to a win-win situation of the small micro-enterprise and the small and medium-sized banks.

The development of the small micro-enterprise needs the favor of banks. The fact proved that the small micro-enterprise make more than the half contribution for the tax and GDP in our country, however, which did not make them get the favor of banks. The same as the small micro-enterprises, the small and medium-sized banks survive hard because of competition. The small micro-enterprise and the small and medium-size banks should rely on each other for a win-win situation. Especially, the small and medium-sized banks usually have advantages in regional market compared with the state-owned banks. Consequently, the small and medium-sized banks are supposed to size the significance opportunity about the financing of the small micro-enterprise to develop itself in the long run. The financing problem of the small micro-enterprises and how the small medium-sized banks size the opportunity to change themselves is the same problem. To solve this difficulty, not only the small micro-enterprises should develop itself, but also the small medium-sized banks should do more efforts than the small micro-enterprises. It won't be effective if conventional ideas and ways are still adopted in solving this problem. So the small and medium-sized banks are supposed to innovate and develop in terms of the small micro-finance services based on the original level. And the core of innovation and development is to overturn the convention. That is to say, carry out small businesses by means of big data thinking, conduct big data analytics, and combine the advantage of the Internet finance with that of its own to finally open source for the financing of the small micro-enterprise. Big data thinking is the whole, Internet is the tool, but the most important is it's self-reform.

\section{The thing which the small and medium-sized banks should do}

Apply the idea of the big data. The small businesses have difficulty in financing simply because the banks want to protect themselves. Taking the security of credit funds into consideration, the banks would usually establish their own credit evaluation standard and assess the credit of those enterprises who have applied for a loan. Due to the disadvantages of little capital, unstable profitability, and weak management foundation, the micro enterprises are unlikely to reach the 
standard of the banks on their loans, causing the banks focus their key credit on those large and medium-sized state-owned enterprises with strong capability, profitability and guaranteed debt and other large private enterprises.

Therefore, the small and medium-sized banks should overcome these drawbacks of the large state-owned banks, and must apply creative strategies, break the conventional thinking and acting ways of the traditional banking industry, command the overall situation through big data, take the way of big data analytics to evaluate the credit criteria of micro enterprises, and set up a more reasonable credit evaluation standard. The small and medium-sized banks employ the new evaluation criteria, which won't make simple credit assessment to the micro enterprises. Instead, they will make deep analysis into different micro enterprises and learn to measure them in professional standards. Take the service industry as an example; it won't make sense if it is judged by the financial statement. More real and proper data can be used to measure and evaluate its credit, such as professional standards, customer capacity and capital flow.

Use the tool of the Internet finance, Speed up self-reform. The small and medium-sized banks have gradually realized that micro enterprises' financing is the significant opportunity of their existence and development. They have changed their attitude from suspicion to accepting micro finance. At the same time, the Internet finance suddenly rise. It first catches the chance of micro finance and wins the advantage. And it provides new accesses for small businesses solving the financing problem in three aspects: increasing the transparency of involved main information, lowering transaction expense of financial services, and digging the potential the demand and supply sides of micro finance services.

Confronting with the impact of Internet finance, the small and medium-sized banks should have a correct understanding of this - challenge as well as opportunity. Although Internet finance owns many advantages, such as low finance costs, no need of collateralized mortgage and rapid, efficient financing, traditional banks are not anything. The small and medium-sized banks should turn pressure into motivation, take actions in innovation, accelerate using technology, upgrade and reform service and products.

In the process of innovation, the small and medium-sized banks should draw support from the Internet finance, and combine it with self characteristics, that is, professional technology and analyzing tools, which means that apart from the help of big data analytics by the Internet finance, they should also analyze the micro enterprises involved professions in period through professional technology and analyzing tools, investigate the concerning markets and combine both advantages together. In addition, the present Internet finance stays in the state of providing the micro enterprises with convenient, fast and lower-cost loan, and the small and medium-sized banks should notice that only providing micro finance credit is not the whole of micro-finance. In essence, what micro enterprises urgently need is to open up channels of funding sources, and obtain more money that can be used. In this sense, the micro enterprises are in need of additional financial service, including settlement and financial management, etc. Such financial services can also help to widen the financing source channel of micro enterprises and solve the essential financing problem. What's more, the small and medium-sized banks can practice some non-financial services like organizing financial knowledge training of the management of micro enterprises, and provide a full range of financial services for micro enterprises depending on the Internet finance and their own features. This promotes the development of the small businesses as well as their own, achieving the win-win effect.

Focus on the rural micro-finance. In the huge camp of the small micro-enterprises, the rural small-enterprises tend to be ignored. In addition, the penetration of the internet finance is not deep in the countryside environment.

The financial channels tend to be narrower, which led to the more urgent financing needs for this part of the small micro-enterprise. For the rural credit cooperatives the small and medium-sized banks ,such as the rural credit cooperatives, in this situation, they are supposed to size the opportunity, innovate independently, make the internet finance as its own tools which carry out the business in the rural small-enterprises. At the same time, the rural financial service would better to 
be perfected to easy the demand of money in the rural financial market, cultivate and develop a competitive rural financial market and promote the common development of the rural smallenterprises.

\section{Summary}

The small micro-finance is a potential share. The small micro-enterprise need to make it's own efforts to overcome their own shortcomings in solving the problem that the financing difficulties of the small micro-enterprise and the development of the small and medium-sized banks. However, in reality, more responsibility and burden fall on the shoulder of the small and medium-sized banks .Only in this way that grasping the situation, adopting the thinking mode of the big date for innovation and change relying on the connected to financial advantages can a road to a win-win situation of the small micro-enterprise and the small and medium-sized banks will be true.

\section{Reference}

[1]HongQiangLi:Countryside and Finance in Guizhou,no.294(2012),P7

[2]ShaoXianWei:Gansu Audit,(2013)

[3]LiXie:Financial Times,(2014)

[4]Information on http://www.jste.gov.cn/gdzxqy/1101118811.htm

[5]XueJiaoJi:Financial Investment,(2014)

[6]JunGuoShao:Farmer’s Daily,(2012)

[7]Information on http://blog.sina.com.cn/s/blog_9722634c01010pnr.html 